\title{
Studies of Reversible Hydrogen Binding in Nano- Sized Materials
}

\author{
Pēteris Lesničenoks ${ }^{1}$, Jānis Zemītis ${ }^{2}$, Jānis Kleperis ${ }^{3}$, Georgijs Čikvaidze ${ }^{4}$, Reinis Ignatāns ${ }^{5}$, \\ ${ }^{1-2}$ Riga Technical University, ${ }^{3-5}$ Institute of Solid State Physics, University of Latvia
}

\begin{abstract}
Experimental review of materials suitable for reversible hydrogen binding in nanoporous and nanosized structures of materials, based on natural zeolite (clinoptilolite) and graphene (exfoliated electrochemically from raw graphite), were analyzed. Characterization of materials with SEM, XRD, EDS and Raman spectroscopy methods and aspects of synthesis of a nanostructured zeolite and a few-layer graphite material was done in this work. It was established from gas analyzer results that hydrogen mass fraction in natural zeolite ranged from $1.1 \%$ to $1.4 \%$, but in the few-layer graphite material - from $0.39 \%$ to $0.46 \%$.
\end{abstract}

Keywords - Hydrogen, storage, graphene, zeolite, graphite.

\section{INTRODUCTION}

To facilitate the transition from fossil fuels to technologies based on clean and renewable resources, problems concerning the energy storage must be solved. Wind and sun are the most popular renewable energy sources, but they are available occasionally or periodically, that is, not always when consumption requires [1]. Compared to electricity, hydrogen is an ideal energy carrier, because it can be stored almost without losses. In transport sector hydrogen fuel cell technologies are currently being commercialized (Toyota, Hyundai from 2015), hydrogen storage in high pressure (700 bar) tanks is used [2]. The technology and economical means to make carboncomposite high pressure tanks capable of providing travel distances up to $700 \mathrm{~km}$ - are well understood and the costs are reasonable. World's largest hydrogen association International Partnership of Hydrogen Energy (IPHE) has gathered information about an impressive number of already realized hydrogen demonstration projects (Table I).

In the near future the demand for inexpensive and "green" hydrogen will increase, especially for transportation purposes. High pressure composite vessels can be charged only using powerful multi-stage compressors, which is profitable at filling stations, but not in the private sector and small farms. Creating a capacious, not too heavy and large containers with porous, solid materials containing stored hydrogen could solve this problem, because these materials can be recharged at low pressures, for example, at which typical electrolyzers work (up to $30 \mathrm{bar}$ ). Regarding the application of this technology for vehicles, the materials with high volumetric and gravimetric densities of hydrogen storage are required [4]. United States Department of Energy (DOE) is focusing primarily on the research and development of on-board vehicular hydrogen storage systems that will allow for a driving range of greater than 300 miles $(480 \mathrm{~km})$ while meeting packaging, cost, safety, and performance requirements to be competitive with currently used vehicles. The targets set by DOE [4] for these solid materials to reach in 2015 are based on application requirements (not on current hydrogen storage technology capabilities) are $6 \%$ of mass fraction for system gravimetric density and $45 \mathrm{~g} / \mathrm{L}$ for system volumetric density.

TABLE I

SUMMARY OF IPHE DEMONSTRATION PROJECTS [3]

\begin{tabular}{|c|c|c|c|c|c|}
\hline $\begin{array}{c}\text { IPHE Partner } \\
\text { Country }\end{array}$ & A & B & C & D & F \\
\hline Australia & 0 & 0 & 0 & 0 & 2 \\
\hline Canada & 16 & 5 & 12 & 34 & 6 \\
\hline China & 3 & 20 & - & 6 & - \\
\hline Germany & 7 & 28 & 13 & 20 & 55 \\
\hline Japan & 12 & 45 & 8 & 5 & 2232 \\
\hline Korea & 5 & 40 & 0 & 4 & 240 \\
\hline New Zealand & 0 & 0 & 0 & 0 & 2 \\
\hline Norway & 2 & 0 & 15 & 0 & 1 \\
\hline United States & 58 & 92 & 25 & 34 & $\sim 2000$ \\
\hline Total & 103 & 230 & 73 & 103 & $\sim 4500$ \\
\hline
\end{tabular}

A - number of hydrogen refilling stations; B - fuel cell vehicles;

C - ICE compressed hydrogen vehicles; D - hydrogen buses;

$\mathrm{F}$ - stationary fuel cells.

Optimum thermodynamic and kinetic windows are needed for hydrogen absorption and desorption in solids at reasonable temperatures and pressures [5]. The pores in zeolites with dimensions of $4 \AA-7 \AA$ are suitable to store hydrogen molecules with kinetic diameter of $2.89 \AA$ ) up to $1.74 \%$ weight fraction, as it is shown, at low temperature $\left(-196^{\circ} \mathrm{C}\right)$ and $\mathrm{H}_{2}$ pressure (15 bar) [6]. Recently, it was announced that at low temperatures $\left(-196^{\circ} \mathrm{C}\right)$ zeolite templated carbons show exceptional gravimetric hydrogen uptake - weight fraction $7.3 \%$ at 20 bar [7], which is the highest recorded for carbon materials. Only some of the research is devoted to hydrogen storage capability in zeolite-type structures at higher temperatures. Weitkamp et al. in 1993 [8] reported that zeolites containing sodalite cages in their structure show hydrogen storage capacity $9.2 \mathrm{~cm}^{3} / \mathrm{g}$, if loaded at $573 \mathrm{~K}$ and at 10.0 MPa.

Using theoretical considerations the authors [9] suggested that a multilayer graphene storage system has good reversibility for chemisorbed hydrogen on corrugated graphene sheets (weight fraction up to $8 \%$ ). The authors [10] proposed to enhance the hydrogen chemisorption by doping the graphitic material with $\mathrm{Pd}$ or $\mathrm{Pt}$ catalyst on which 
hydrogen molecules disassociate and the atomic hydrogen then can easier fill the pores of the material. The drift or the spillover of atomic hydrogen onto carbon surface was investigated ten years ago, when Lueking et al. [11] detected that the hydrogen uptake as mass fraction in $\mathrm{Pd}$-doped carbon nanotubes (SWNT) was up to $0.1 \%$ at 1 bar and $25^{\circ} \mathrm{C}$. A third possibility also exists - to adjust hydrogen adsorption enthalpy by introducing nano-grains of hydride-forming material between the sheets of graphene in stacks, for example, lithium or magnesium [12] .

Our research [13] shows that it is possible to reach hydrogen adsorption capacity of $6.2 \%$ mass fraction for $\mathrm{Mg}$ ion exchanged zeolite (clinoptilolite) using a specific technique - the loading of material with hydrogen at high temperature and following it with cooling down to room temperature. The mechanism of hydrogen encapsulation in the pores of zeolite is proposed to explain such a high hydrogen uptake.

In this paper we used different techniques to test previous results and to characterize zeolite and few-layer graphite materials for hydrogen storage capability at room temperature.

\section{EXPERIMENTAL PART}

Samples were prepared by ion exchange with $\mathrm{MgCl}_{2}(1$ $\mathrm{mol} / \mathrm{l})$ and washing in deionized water. Zeolite - clinoptilolite sample was characterized using XRD as natural clinoptilolite with some ferrierite impurities [14] and furtherer investigated by EDS to determine more precise $\mathrm{Si} / \mathrm{Al}$ ratio (Table II and Table III). Due to different hydrogen loading pressure (5 bar) and exposure to air, varying results were expected.

TABLE II

NATURAL CLINOPTILOLITE - EDS SPECTRA WITH Si/AL RATIO 10.319

\begin{tabular}{|l|l|l|l|}
\hline Element & Series & Norm. at., \% & Error, \% \\
\hline Aluminium & K-series & 2.618932574 & 0.218606073 \\
\hline Silicon & K-series & 28.80796765 & 1.889704057 \\
\hline Oxygen & K-series & 65.70334441 & 6.983858719 \\
\hline Potassium & K-series & 1.011897176 & 0.107846702 \\
\hline Sodium & K-series & 0.352886243 & 0.065595332 \\
\hline Iron & K-series & 0.537640653 & 0.106374724 \\
\hline Carbon & K-series & 0.313475372 & 0.391040007 \\
\hline Magnesium & K-series & 0.332134442 & 0.058916271 \\
\hline Calcium & K-series & 0.321721484 & 0.060207677 \\
\hline
\end{tabular}

To obtain a few-layer graphite (FLG), the electrochemical exfoliation was used, using graphite industrial waste rod as the working electrode. Setup parameters were as follows: 5:5 (s) pulse sequence, $\pm 10 \mathrm{~V}$ amplitude. Electrolyte with varying concentrations $(0.25 \mathrm{~mol} / \mathrm{l}, 0.5 \mathrm{~mol} / \mathrm{l}$ or $1 \mathrm{~mol} / \mathrm{l})$ and counter electrode ( $\mathrm{Cu}$ plate or graphite) were used to find optimal parameters for exfoliation process. An important step is purification - FLG material is the lightest material and can be partially separated using centrifugation or sedimentation. From our experience, sedimentation was more useful. To obtain material with higher quality, samples were exposed to $\mathrm{Ar} / \mathrm{H}_{2}$ gas flow at $300{ }^{\circ} \mathrm{C}$ for $3 \mathrm{~h}$, thus guarantying a higher degree of reduction $[14,15]$.

The initial samples were characterized by X-ray diffraction (XRD) using Bruker D8 model, scanning electron microscopy (SEM) using Hitachi S-400N model, the elemental composition of samples was determined using energy dispersive spectroscopy (EDS).

TABLE III

SYNTHESIZED CLINOPTILOLITE SAMPLE EDS WITH SI/AL RATIO 8.372

\begin{tabular}{|l|l|l|l|}
\hline Element & Series & Norm. at., \% & Error, \% \\
\hline Oxygen & K-series & 62.03790834 & 5.859888236 \\
\hline Silicon & K-series & 29.63537623 & 1.882520741 \\
\hline Aluminium & K-series & 3.541808206 & 0.265028459 \\
\hline Potassium & K-series & 2.728274732 & 0.202826426 \\
\hline Sodium & K-series & 0.372240588 & 0.056766053 \\
\hline Magnesium & K-series & 0.087593441 & 0.033077223 \\
\hline Carbon & K-series & 1.596798465 & 0.344494868 \\
\hline
\end{tabular}

\section{METHODS}

Two significantly different methods to measure hydrogen uptake were used. The first was Sievert type volumetric method using PCT - Pro 2000 (SETARAM Instrumentation) a fairly slow experiment to determine kinetics and PCT graphs. The second was gas analysis of samples using HORIBA EMGA - 830AC Hydrogen Oxygen Nitrogen gas analyzer (experiment limited till $100 \mathrm{~s}$ due to sensor saturation).

Using this method the loaded sample was burned in $\mathrm{He}$ plasma and compared to hydrogen free samples, which had been degassed. The percentage of gas content was recalculated from the mass of sample.

\section{RESULTS}

The partial sorption level of clinoptilolite determined from volumetric measurements was $\sim 0.6 \%$ mass fraction, also after hydrogenation, natural clinoptilolite sample had changed color to more grey tone both in Sievert type device and in external hydrogenation apparatus for gas analysis measurements.

XRD studies show that zeolite indeed had the heulandite type structure as determined by XRF as clinoptilolite; yet the FLG's were recognized as graphite (Fig. 8).

Gas analyzer data shows hydrogen content in natural zeolite from $1.1 \%$ to $1.4 \%$ of mass fraction (Fig. 1, Fig. 2) depending on the loading method (PCT apparatus or the external hydrogenation) for gas analysis measurements.

SEM images of FLG samples (Fig. 3, Fig. 4) show opened few-layer graphite/graphene structures, with higher surface area than it would be, if stacked together (determined by BET method $0.43 \mathrm{~m}^{2} / \mathrm{g}$ for Mg FLG and $12.4 \mathrm{~m}^{2} / \mathrm{g}$ for reduced FLG. The calculated thickness from SEM images (Fig. 3, Fig. 4) was around 37 and $54 \mathrm{~nm}$ as multilayer materialand up to $200 \mathrm{~nm}$ in thickness, containing voids between graphene sheets sized from 
couple of nm and up to several $\mu \mathrm{m}$. Using SEM images of graphene/graphite type structures, it was determined that chemical exfoliation produces open FLG structures. Reducing process broke up the stacks of material, leaving open structures deep in the particles, but also exposed single sheets of FLG.

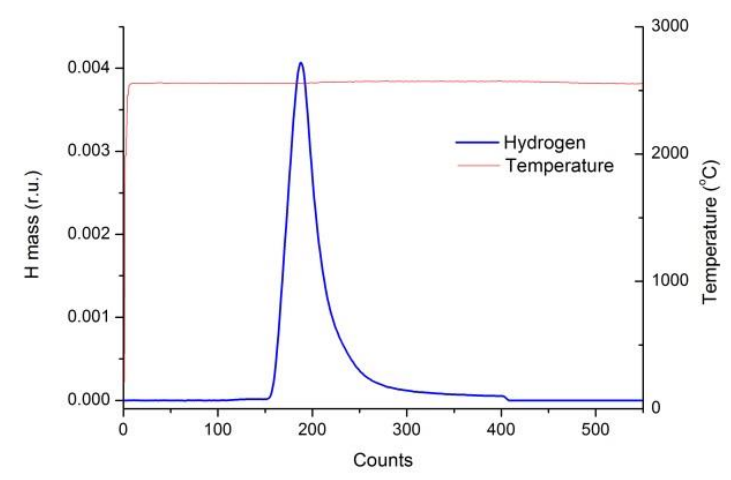

Fig. 1. Gas analyzer data for zeolite after hydrogenation in a Sievert type device $P C T$ - PRO 2000.

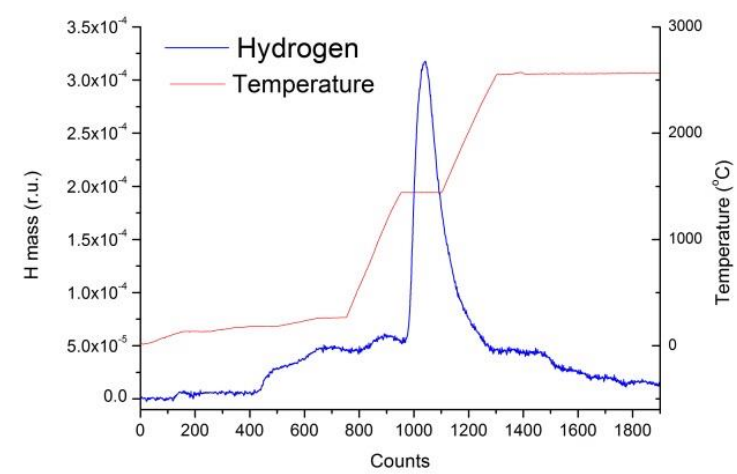

Fig. 2. Gas analyzer data for zeolite after hydrogenation by an external hydrogenation device.

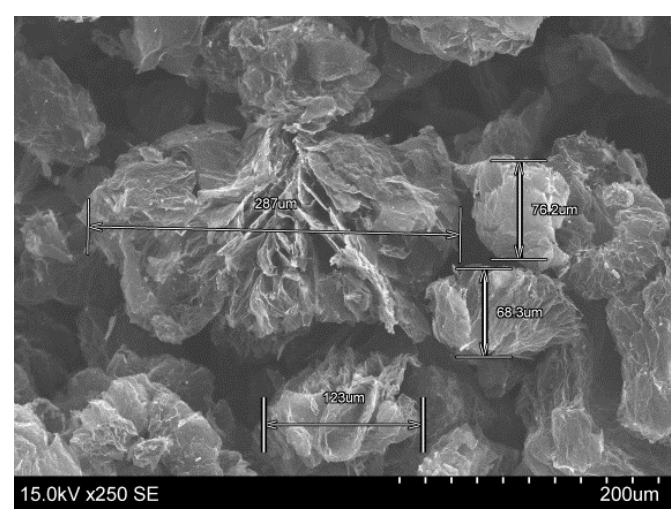

Fig. 3. SEM image of FLG particles.

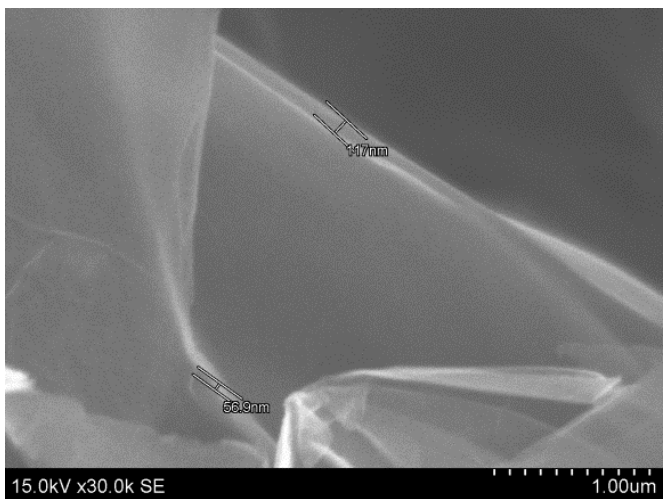

Fig. 4. SEM image of FLG particle structures.

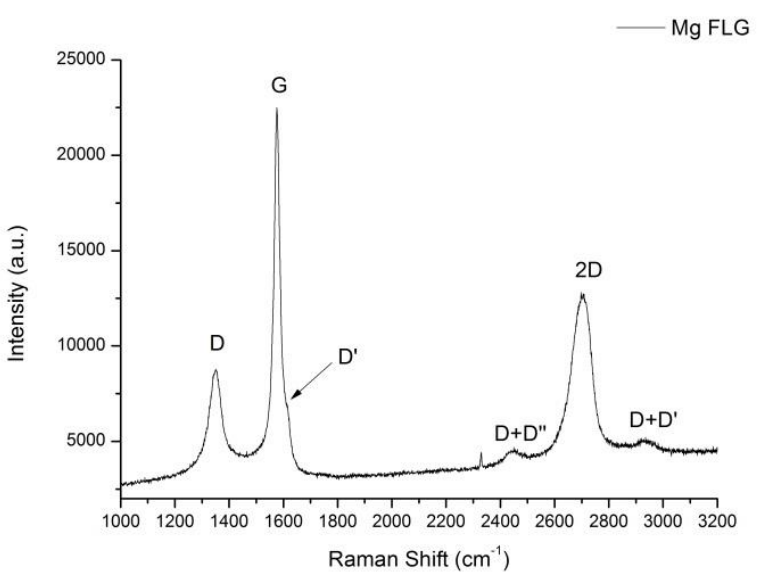

Fig. 5. Raman spectra of Mg FLG structures.

XRD (Fig. 6) showed graphitic structure with additional peaks of an impurity from production.

EDS XRF analysis showed the presence of elements with larger atomic number than $\mathrm{Na}$. The spectra showed mostly $\mathrm{Fe}$, $\mathrm{Si}$ and some $\mathrm{Ti}$ impurities in the graphite substrate material. The EDS analysis for FLG shows sulfur impurities and some chlorine, as well as $\mathrm{Al}, \mathrm{Si}, \mathrm{Fe}$, and Ti (Table IV).

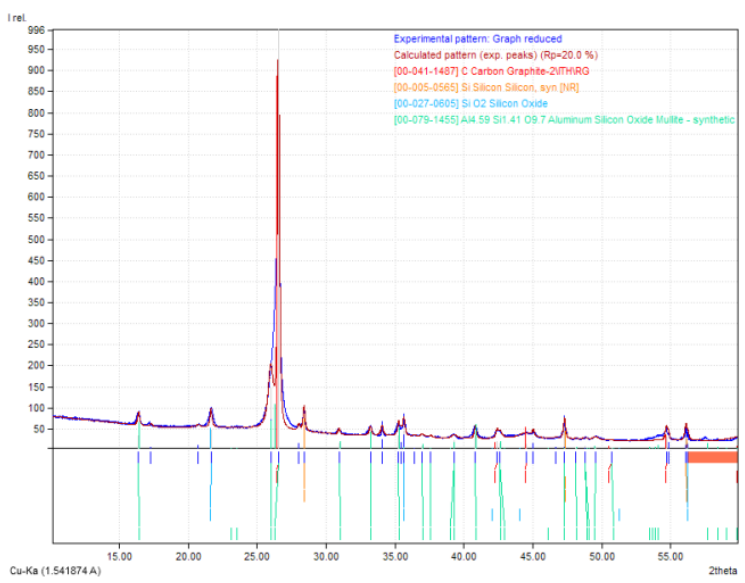

Fig. 6. XRD pattern of FLG powder.

Raman scattering was used to identify the presence of graphene (as it can be seen in Fig. 5) for obtained multistacks of graphene sheets. Micro-Raman measurements were conducted using a Renishaw inVia spectrometer equipped with an argon laser with wave length $514.5 \mathrm{~nm}$. Raman scattering 
spectra were acquired at room temperature through a microscope objective with $20 \times$ magnification. The spectral signal was dispersed using grating that had 2400 grooves in $1 \mathrm{~mm}$ onto a Peltier cooled $\left(-60{ }^{\circ} \mathrm{C}\right) \mathrm{CCD}$ detector. The laser excitation power was $10 \mathrm{~mW}$. G peak showed the presence of graphitic structures. D peak showed the amount of defects in graphene planes. Intensity ratio of $2 \mathrm{D} / \mathrm{G}$ peaks indicated the number of layers in graphitic materials. The $2 \mathrm{D}$ peak had lower intensity than the $G$ peak - thus indicating that the material consisted of more than one layer. D' peak is usually produced by intravalent scattering or hole scattering in the material. D' + D and D" + D indicated edge defects alignment between planes was not consistent and zigzag / armchair edge mix-up was present in FLG material [17].

TABLE IV

\section{MG FLG EDS DATA}

\begin{tabular}{|l|l|l|l|}
\hline Element & Series & Norm. at.. \% & Error. \% \\
\hline Oxygen & K-series & 28.31609752 & 10.65808247 \\
\hline Carbon & K-series & 70.18533945 & 21.68381901 \\
\hline Sulfur & K-series & 0.684214243 & 0.084989106 \\
\hline Silicon & K-series & 0.129782837 & 0.038174867 \\
\hline Aluminium & K-series & 0.058680308 & 0.032189277 \\
\hline Sodium & K-series & 0.307062192 & 0.060594815 \\
\hline Potassium & K-series & 0.091614128 & 0.035981395 \\
\hline Chlorine & K-series & 0.227209318 & 0.047522642 \\
\hline
\end{tabular}

Preliminary experiments were done to test hydrogen absorption capability in graphene sheet stacks, using thermal absorption/desorption methods. Two different samples were collected from both exfoliation and plasma methods - the light fraction of material, which floated on the top of solution, and the heavy fraction, which sank at the bottom of the solution.

A study of hydrogenated Mg FLG samples was done using Horiba EMGA - 830AC gas analyzer. During the burning of samples at different rates reaching $6 \mathrm{~kW}$ and around $3000{ }^{\circ} \mathrm{C}$, the absolute hydrogen mass fraction in samples was determined to be $0.39 \%-0.46 \%$.

\section{DISCUSSION}

Synthesized materials had acceptable quality, showed the needed phases for zeolites and the desired pike in Raman spectra (for few-layer graphite powder), see Fig. 5. Better purifying methods could allow the use of waste material as a reliable resource for synthesis of few-layer graphite powder.

Clinoptilolite shows a promising tendency for higher hydrogen storage capacity, but further studies are needed to repeat the obtained results. Especially for gas analyzer experiments that show the exact temperatures in which most desorption occurs, it would be best to use this technique step by step - not applying the max voltage and destroying the mineral.

Hydrogen can interact with graphene in FLG structures by physisorption and chemisorption; another possibility is to exploit intercalation of hydrogen between FLG sheet stacks (distance between the sheets is important) [18].

As reported above, graphene sheets that were not doped showed hydrogen storage possibilities around $0.55 \%$ mass fraction. Intercalation of FLG with magnesium or lithium ions would be necessary to enhance the amount of bound hydrogen in the material. Reached results show more precise information about processes which are happening during hydrogen sorption in high surface area materials.

\section{CONCLUSION}

In our work an artificial zeolite, which corresponds to clinoptilolite regarding XRD analysis, was successfully synthesized. Based on XRD data, the tested samples of natural zeolite were clinoptilolite with crystalline ferrierite and quartz impurities. From volumetric measurements it was determined that hydrogen uptake in the natural zeolite at room temperature was around $\sim 0.6 \%$ mass fraction and from gas analyzer data it was determined that the mass fraction was from $1.1 \%$ to $1.4 \%$.

Few-layer graphite material with thickness of sheet stacks around $37 \mathrm{~nm}$ and $54 \mathrm{~nm}$ was obtained from raw graphite rod using simple electrochemical exfoliation method. Measured Raman spectra proved the existence of graphene sheets in the exfoliated few-layer graphite. The gas analyzer was applied to measure the amount of hydrogen in the hydrogenated exfoliated few-layer graphite and the values from $0.39 \%$ to $0.46 \%$ mass fraction were obtained.

\section{ACKNOWLEDGMENT}

Authors acknowledge Latvian Council of Science Cooperation Project No. 666/2014 and National Research Program in Energy LATENERGI for financial support.

Part of the results obtained in colaboration with LEI Marius Urbonavičius, Simona Tučkute, Darius Milčius, Martynas Lielis at Lithuanian Energy Institute - Center for Hydrogen Energy Technologies, Kaunas, Lithuania with support from the COST Action MP1103 "Nanostructured materials for solid-state hydrogen storage".

\section{REFERENCES}

1. Bavykin, D. V., Zuttel, A., Borgschulte, A., Schlapbach, L. (eds.): Hydrogen as a Future Energy Carrier, J. Appl. Electrochem., vol. 38, no. 10, pp. 1483-1483, May 2008.

2. Toyota unveils game changer hydrogen-powered car - RT News. [Online]. Available: http://rt.com/news/206667-toyota-hydrogenpowered-car/. [Accessed: 11-Nov-2014].

3. International Partnership for Hydrogen and Fuel Cells in the Economy. [Online]. Available: http://www.iphe.net/resources/demonstration.html. [Accessed: 11-Nov-2014].

4. DOE Hydrogen and Fuel Cells Program: Hydrogen Storage. [Online]. Available: http://www.hydrogen.energy.gov/storage.html. [Accessed: 11Nov-2014].

5. Klebanoff, L. Hydrogen Storage Technology: Materials and Applications CRC Press Book, 2012. [Online]. Available: http://www.crcpress.com/product/isbn/9781439841075. [Accessed: 11Nov-2014].

6. Dong, J., Wang, X., Xu, H., Zhao, Q. and Li, J. Hydrogen storage in several microporous zeolites, Int. J. Hydrogen Energy, vol. 32, no. 18, pp. 4998-5004, Dec. 2007. http://dx.doi.org/10.1016/j.ijhydene.2007.08.009 
7. Masika, E. and Mokaya, R. Exceptional gravimetric and volumetric hydrogen storage for densified zeolite templated carbons with high mechanical stability, Energy Environ. Sci., vol. 7, no. 1, p. 427, Dec. 2014. http://dx.doi.org/10.1039/C3EE42239A

8. Weitkamp, J. Zeolites as media for hydrogen storage*1, Int. J. Hydrogen Energy, vol. 20, no. 12, pp. 967-970, Dec. 1995. http://dx.doi.org/10.1016/0360-3199(95)00058-L

9. Tozzini, V. and Pellegrini, V. Prospects for hydrogen storage in graphene., Phys. Chem. Chem. Phys., vol. 15, no. 1, pp. 80-9, Jan. 2013. http://dx.doi.org/10.1039/C2CP42538F

10. Chen, C.-H., Chung, T.-Y., Shen, C.-C., Yu, M.-S., Tsao, C.-S., Shi, G.-N., Huang, C.-C., Ger, M.-D. and Lee, W.-L. Hydrogen storage performance in palladium-doped graphene/carbon composites, Int. J. Hydrogen Energy, vol. 38, no. 9, pp. 3681-3688, Mar. 2013. http://dx.doi.org/10.1016/j.ijhydene.2013.01.070

11. Lueking, A. Hydrogen spillover to enhance hydrogen storage — study of the effect of carbon physicochemical properties, Appl. Catal. A Gen., vol. 265, no. 2, pp. 259-268, Jul. 2004. http://dx.doi.org/10.1016/j.apcata.2004.01.019

12. Spyrou, K., Gournis, D. and Rudolf, P. Hydrogen Storage in GrapheneBased Materials: Efforts Towards Enhanced Hydrogen Absorption, ECS J. Solid State Sci. Technol., vol. 2, no. 10, pp. M3160-M3169, Sep. 2013. http://dx.doi.org/10.1149/2.018310jss

13. Kleperis, J., Lesnicenoks, P., Grinberga, L., Chikvaidze, G. and Klavins, J. Zeolite as Material for Hydrogen Storage in Transport Applications / Ceolīta Kā Ūdeṇraža Uzglabāšanas Vides Izpēte, Latv. J. Phys. Tech. Sci., vol. 50, no. 3, pp. 59-64, Jan. 2013. http://dx.doi.org/10.2478/lpts-2013-0020

14. Lesnicenoks, P., Sivars, A., Grinberga, L. and Kleperis, J. Research Of Hydrogen Adsorption Dynamics In Natural Zeolite And Glass/Metal Hydride Composites, in E-MRS 2012 SPRING MEETING -Solid State Ionics: Mass and Charge Transport across and along Interfaces of Funnctional Materials, 2012, p. 22.

15. Huh, S. H. and Korea, S. Thermal Reduction of Graphene Oxide, in Physics and Applications of Graphene - Experiments, M. Sergey, Ed. InTech, 2010, p. 540.

16. Pie, S. and Cheng, H.-M. The reduction of graphene oxide, Carbon N. Y., vol. 50, no. 9, pp. 3210-3228, Aug. 2012 http://dx.doi.org/10.1016/j.carbon.2011.11.010

17. Ferrari, A. C. and Basko, D. M. Raman spectroscopy as a versatile tool for studying the properties of graphene., Nat. Nanotechnol., vol. 8, no. 4 pp. 235-46, 2013. http://dx.doi.org/10.1038/nnano.2013.46

18. Spyrou, K., Gournis, D. and Rudolf, P. Hydrogen Storage in GrapheneBased Materials: Efforts Towards Enhanced Hydrogen Absorption, ECS J. Solid State Sci. Technol., vol. 2, no. 10, pp. M3160-M3169, Sep. 2013. http://dx.doi.org/10.1149/2.018310jss

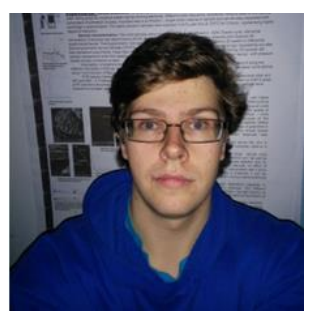

Pēteris Lesničenoks, $\quad B c$. sc. ing. in materials science (2013), is a master level student of materials science in Riga Technical University. His fields of study include materials for hydrogen energetics and hydrogen storage. He as an engineer in the Laboratory of Hydrogen Energy Materials in the Institute of Solid state Physics, University of Latvia.

E-mail: peteris.lesnicenoks@rtu.lv

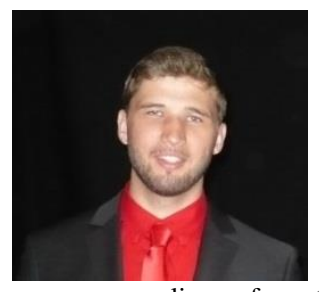

Jānis Zemītis, Bc. sc. ing. in chemical engineering, is a researcher in Hydrogen Energy Materials Laboratory at the Institute of Solid State Physics, University of Latvia. $\mathrm{He}$ is currently studying in master's program Materials Science in Riga Technical University. His bachelor's thesis research field was organic chemistry, renewable

energy, recycling of materials, semiconductors, inorganic chemistry, materials science.

$\mathrm{He}$ is a research scientist in the Laboratory of Hydrogen Energy Materials at the Institute of Solid State Physics, University of Latvia. He also researches recycling of materials in a private company. He has participated in different projects about renewable (solar, wind, water) energy and materials science. He has more than 5 publications in organic chemistry and materials science.

E-mail: zemitis.janis69@gmail.com

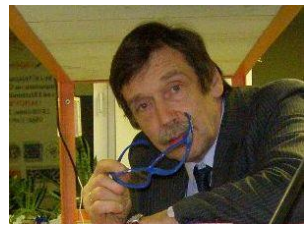

Jānis Kleperis, Dr. phys., senior research scientist, head of Laboratory of Hydrogen Energy Materials at the Institute of Solid State Physics, University of Latvia, has participated in various local and international projects about materials science, energy and environment, and is an author of more than 150 scientific publications. J. Kleperis has doctoral degree diploma. His PhD thesis was "Research of Color Centers in Tungsten Trioxide" (1984; 1992). His fields of specialization are: semiconductor physics, materials science, optical and electrical properties of materials, solid state ionics, electrochromic phenomena, chemical gas sensors, instruments with artificial intellect (electronic nose), hydrogen gas sensors, materials for hydrogen storage, $\mathrm{Li}$ and metal hydride batteries, electrolysis, membranes and MEA for fuel cells, DOAS for air pollution monitoring, air pollution measurement, emission calculations, forecasts Janis Kleperis is a member of International Society of Electrochemistry. E-mail: kleperis@latnet.lv

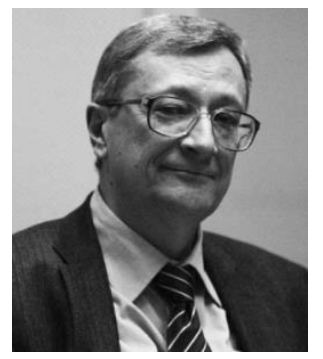

George Čikvaidze, Dr. phys., senior research scientist at the Institute of Solid State Physics, University of Latvia. He has been a part of the staff of the Institute of Solid State Physics since 1978. George Chikvaidze obtained a diploma in physics from the University of Latvia and a of Dr. phys. degree for the thesis "Spectra and structure of molecular crystals of arsenic and phosphorus" in 1992. Fields of scientific activity: semiconductor physics, materials science. Specialization and scientific experience: Infrared and Raman spectroscopy. He has participated in various local and international projects related to materials science, energy and environment, he was a scientific adviser for two international scientific projects and he is an author of more than 60 scientific publications.

E-mail: georgc@cfi.lu.lv

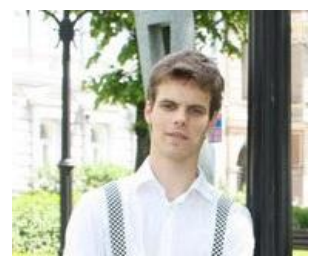

Reinis Ignatāns, $B c$. phys. is an engenieer at Institute of Solid State Physics, University of Latvia. He specializes in scientific and standard measurements using an X-ray diffractometer, X-ray diffraction analysis, apparatus maintenance and Rietveld analysis. He is currently studying physics at master's level. He has published his work in

these scientific fields: ferroelectrics and optical materials.

E-mail: reinis.ignatans@gmail.com

Pēteris Lesničenoks, Jānis Zemītis, Jānis Kleperis, Georgijs Čikvaidze, Reinis Ignatāns. Atgriezeniskas ūdeṇraža saistī̌anās spējas pētījumi nanomateriālos.

Salīdzinot elektroenerǵijas uzglabāšanas veidus, ūdeņradis ir daudz efektīvāks enerǵijas uzkrāšanas līdzeklis nekā baterijas vai kondensatori, jo to iespējams uzglabāt gandrīz bez zudumiem. Šì brīža tehnologijijas l̦auj uzglabāt ūdeņradi tītajos oglekḷa šķiedru kompozīta balonos augstā spiedienā, taču zema spiediena tehnoloǵijas ir nozīmīgs solis drošības un nākotnes pielietojumu, kā arī tehnologijijas vienkāršošanas virzienā. Darba mērķis bija atrast efektīvus ūdeņraža sorbcijas materiālus, kā arī modificēt pieejamos reciklējamos tehniskos metalurğijas atkritumus, lai 
tos būtu iespējams izmantot ūdeņraža energêetikas jomā. Darbā dots īss pārskats par materiāliem un to piemērotību atgriezeniskai ūdeņraža saistī̌anai mezoporainu materiālu nanoporās un uz virsmas, kā arī eksperimentāli iegūti rezultāti par dabīgā ceolīta (klinoptilolīta) un vairākslāņu grafîta (iegūts elektroķīmiskas atslāņošanas cel̦ā no grafîta) ūdeņraža adsorbcijas spēju. Gan ceolītu, gan vairākslāņu grafìta materiālu morfoloǵija, sastāvs un struktūra raksturoti izmantojot skenējošo elektronu mikroskopiju, rentgenstruktūranalīzi Furjē transformāciju infrasarkano spektroskopiju, enerǵijas dispersijas rentgenstaru spektroskopiju (EDS) un Ramana spektroskopiju. Pēc termiskas apstrādes ūdeņraža atmosfērā (5 bar) adsorbcijas/desorbcijas iekārtā PCT-Pro2000 un/vai speciāli izveidotā neliela tilpuma cilindriskā kamerā, materiālos saistītā ūdeņraža daudzums noteikts izmantojot gāzu analizatoru Horiba EMGA - 830 AC, kurā paraugu sadedzināja hēlija plazmā. Ceolīta paraugu ūdeņraža sorbcijas spēja ir robežās no $0.6 \%$ līdz $1.4 \%$ (masas daḷa), bet vairākslāṇu grafita materiāliem tā ir robežās no $0.39 \%$ līdz $0.46 \%$.

Strādājot ar elektroḳīmisko vairākslāņu grafīta iegūšanas metodi, noskaidrota optimālā elektrolīta molaritāte ātrai vairākslāņu grafìta materiāla iegūšanai $-1 \mathrm{~mol} / 1 \mathrm{H}_{2} \mathrm{SO}_{4}$ bez papildus piedevām. Tālākos pētījumos tiks skaidrota vairākslānsu grafita struktūrā interkalētu dažādu metālu jonu (Mg, Li, Pd) ietekme uz ūdeņraža sorbcijas/desorbijas spēju materiālā, ar mērḳi atrast labāko materiālu ūdeņraža uzglabāšanai.

Петерис Лесниченокс, Янис Земитис, Янис Клеперис, Георгй Чикваидзе, Реинис Игнатанс. Исследования способности обратимого связывания водорода в наноразмерных материалах.

По сравнению с современными способами хранения электроэнергии (например, батареями или конденсаторами), водород более эффективен, т.к. его можно хранить почти без потерь. В наше время для хранения водорода используют специальные композитные баллоны из углеродного волокна под высоким давлением, поэтому технологии хранения при низком давлении - это важный шаг на пути к безопасному использованию водорода в будущем и упрощению этого метода хранения. Цель работы состоит в том, чтобы найти наиболее эффективные материалы для сорбции водорода, а также успешно модифицировать доступные перерабатываемые технические отходы металлургии таким образом, чтобы они могли бы быть использованы в отрасли водородной энергетики.

В работе представлен краткий обзор исследований материалов и их способностей обратимого связывания водорода в порах и на поверхности наноматериалов. Обзор основан на исследованиях природного цеолита (клиноптилолита) и графена, полученного из графита методом электрохимической эксфолиации. Свойства порошковых материалов (цеолиты и образец из нескольких слоев графита (FLG)) были изучены при помощи СЭМ, РДА, ИК-Фурье, ЭДС и РАМАН. Согласно результатам, полученным при помощи газового анализатора Horiba EMGA - 830 AC, в котором образец сжигается в плазме гелия, способность поглощать водород у цеолита находится в интервале от $0,6-1,4$ массовых \%, а для образцов из нескольких слоев графита от 0,39-0,46 массовых \%. Образцы насыщались водородом двумя методами: при помощи установки для определения сорбции/десорбции, изменением объема РСТ - Рrо 2000 , а так же при использовании специально изготовленной цилиндрической камеры, которую можно нагревать и создавать внутри вакуум. В обоих случаях эксперимент проводился при давлении водорода 5 бар.

При использовании электрохимического метода для быстрого получения порошкового образца из нескольких слоев графита (FLG) была выявлена оптимальная молярность электролита - 1 моль / л $\left(\mathrm{H}_{2} \mathrm{SO}_{4}\right)$. Дальнейшие исследования будут сосредоточены на изучении влияния интеркаляции ионов металлов $(\mathrm{Mg}, \mathrm{Li}, \mathrm{Pd})$ в структуры из нескольких слоев графита на сорбцию/десорбцию водорода в материале с целью найти наиболее эффективный материал для хранения водорода. 